\title{
Neurodevelopmental Changes in Offspring Prenatally Exposed to Opioids in Human Children and Rodent Models: A Review
}

\author{
Eunice B. Quagraine*
}

\begin{abstract}
The number of infants born to opioid-dependent pregnant women in North America is a growing problem. Studies that focus on the long-term effects of neurodevelopmental changes of prenatal opioid exposure in human infants are however limited. The use of rodent models to evaluate these changes may provide some insight. This review focuses on studies of rodent models exposed to opioids such as morphine, heroin, oxycodone, buprenorphine, methadone, and I- $\alpha$ acetylmethadol in utero and briefly discusses the neural and behavioural effects in human children. Most of the rodent studies reported the following neural effects: increases in caspase-3 and Bax/Bcl-2 ratio, altered NMDA activity, and decreases in BDNF expression in the offspring prenatally exposed to opioids. In addition, they showed decreases in synaptic plasticity, LTP, LTD, dendritic length, and dendritic branch number. The exposed rodent offspring were more inclined to perform poorly in the behavioural tests. Likewise, some of the human studies reported a significant difference between the exposed group and the control; however, other studies reported insignificant or no significant differences after correcting for covariates. Most of the studies suggest an impairment in learning and memory in the rodent offspring and deficits in behaviour and cognition in human children; however, this was not always the case. It is still not clear whether the effects of prenatal opioid exposure are due to the opioid itself being the prime factor, as various factors may also contribute to the results. Further studies of the effects of early opioid exposure on neurodevelopment in the offspring are required.
\end{abstract}

Keywords: opioid, prenatal exposure, neurodevelopment, addiction, hippocampus

*Department of Anatomy, Physiology and Pharmacology, College of Medicine, University of Saskatchewan, Saskatoon, SK, Canada Correspondence: ebq08o@mail.usask.ca

University of Saskatchewan Undergraduate Research Journal Volume 5, Issue 2, 2019

(C) 2019 Eunice B. Quagraine. This open access article is distributed under a Creative Commons Attribution Non-commercial 4.0 license. 


\section{Introduction}

Opioids are a broad class of drugs including both natural, semi-synthetic, and synthetic drugs that act on opioid receptors in the body. The number of infants born to opioiddependent pregnant women in Canada is a growing problem, especially in Ontario. In fact, a study by Brogly et al. (2017) observed that there was a 16-fold increase in the number of mother and infant pairs who had been affected by opioid dependence in Ontario from 2002 to 2014. The rise in opioid use by women of the childbearing age is also prevalent in the United States, as seen by the increase in annual hospital charges for neonatal abstinence syndrome (NAS) from $\$ 190$ million to $\$ 720$ million between years 2000 and 2009 (Patrick et al., 2012).

It is well known that infants born to opioid-using or abusing mothers are at high risk of developing NAS. NAS is a withdrawal syndrome that may occur shortly after the infant's supply of the opioid is cut off after delivery or the dissociation of the maternal-placental-fetal unit. Furthermore, central nervous system (CNS) hyperirritability, autonomic nervous system dysfunction, and gastrointestinal disturbances are characteristics of this withdrawal syndrome (Stover \& Davis, 2015). The increased prevalence of NAS can signify that either pregnant women are seeking help and receiving treatment for their addiction with opioid maintenance therapy (the current intervention for opioidabusing pregnant women) to slowly relieve their addiction or dependence and prevent withdrawal symptoms, or that more women of the childbearing age are abusing opioids. The uncertainty about the cause of increased NAS prevalence, due to lack of information, highlights the difficulty in managing the growing epidemic of opioid abuse in women.

Unfortunately, only a limited number of studies focus on the long-term effects of prenatal opioid exposure in human infants and the neurodevelopmental changes that may arise. It is indeed important to study the postnatal effects that prenatal opioid exposure has on the fetus's brain during the critical period. As mentioned, a small number of studies have evaluated the long-term effects of prenatal opioid exposure in human infants. These studies show mixed results of anxiety, and of behavioural, psychomotor, cognitive, learning, and memory changes that may occur in the prenatally-exposed children. Contradictory results in human studies may arise from challenges in controlling factors that may influence the opioid effects, such as the use of additional drugs or substances. In cases where many factors influence the results, it is reasonable to turn towards animal model studies. Rodents have a shorter gestational period (about 22 days for rats and mice) compared to humans (280 days) (Semple et al., 2013), and allow for more control over various factors.

This paper will focus on the neurodevelopmental effects of early opioid exposure in rodents and will briefly discuss the neurodevelopmental changes in humans. The goal of this review is to assess whether prenatal opioid exposure in rodent models and humans influences neurodevelopment in the offspring.

\section{Methods and Background Information}

\subsection{Literature Search}

A search through ULibrary and PubMed databases was performed and included title/abstract or text searches using the terms opioid, neurodevelopment, prenatal, learning, memory, and rodent. Further references from reviewed articles that contained the aforementioned terms were also considered. Studies that investigated a combination of opioids with other drugs were included as it is common to use opioids alongside other substances such as nicotine and alcohol (Byrnes \& Vassoler, 2017). The studies on animal models were restricted only to rodents, namely rats or mice, to provide a more specific target species.

This review contains summaries of the observed neural and behavioural effects on humans and rodents prenatally exposed to opioids. Each study is summarized based on the findings reported by the author(s). The following sections provide background information on opioids, the hippocampus, and learning and memory processes related to the reviewed studies.

\subsection{Opioid Binding in the Hippocampus}

As mentioned previously, opioids are a broad class of drugs including both natural, semi-synthetic, and synthetic drugs that act on opioid receptors in the body, whereas opiates are a specific class of drugs comprising of naturally derived drugs from the Opium poppy. The studies in review investigated the effects opiates such as morphine, heroin, and I- $\alpha$ acetylmethadol (LAAM), as well as semi-synthetic/synthetic opioids such as methadone, buprenorphine, and oxycodone had on prenatal neurodevelopment. Other opiates or semisynthetic/synthetic opioids such as fentanyl, codeine, and hydrocodone were not specifically studied in the papers reviewed, possibly due to the difficulty in obtaining these drugs for reasons such as cost or availability.

Semi-synthetic/synthetic opioids and opiates commonly act on opioid receptors of the subtypes mu, kappa, or delta and each of these three opioid receptors has been found in the hippocampus (Polunina \& Bryun, 2013). Studies have found that opioid binding to these receptors has a negative impact on adult hippocampal functioning (Wang \& Han, 2009; Cominski, Ansonoff, Turchin, \& Pintar, 2014). Furthermore, studies have shown that opioid receptor 
antagonists, such as naloxone and naltrexone, have a positive impact on adult hippocampal functioning (Cominski et al., 2014). Therefore, it is suggested that opioid binding plays a role in hippocampal-associated learning and memory. Moreover, Klausz et al. (2011) stated that opiates appear to selectively accumulate in the nervous tissue of the exposed offspring possibly due to an increase in the permeability of the blood-brain barrier (BBB) to the opiate. This increase in permeability to opiates in the BBB appears to affect the development of the CNS, which may cause long-term delays or changes in the development of the offspring (Klausz et al., 2011). These findings may have prompted researchers to further investigate the effects opioids have on early neurological development, such as learning and memory changes.

\subsection{Neuroscience of Learning and Memory}

Most of the studies in this review investigate the impact prenatal opioid exposure has on learning and memory. In fact, evidence supports the proposal that opioids influence the activity of hippocampal neurons, and hippocampal neurogenesis (Byrnes \& Vassoler, 2017). Apoptotic regulators: caspase-3, B-cell lymphoma 2 (Bcl-2), and Bcl-2 associated protein $X(B a x)$ are expressed in the hippocampus of rodents and humans and are known to modulate the apoptotic pathway in the hippocampus (Wang \& Han, 2009). Increased expression of caspase-3 and an increased ratio of $\mathrm{Bax} / \mathrm{Bcl}-2$ are typical signs of increased apoptotic signaling (Nasiraei-Moghadam, Kazeminezhad, Dargahi, \& Ahmandiani, 2010). In contrast, brain-derived neurotrophic factor (BDNF) (also found in the hippocampus of rodents and humans) is a neurogenesis modulator involved in neuronal survival and development (Bear, Connors, \& Paradiso, 2016). A decrease in the expression of BDNF is therefore a typical sign of decreased neurogenesis. An increase in apoptosis and a decrease in neurogenesis in the hippocampus reveal signs of negatively altered learning and memory processes.

The hippocampus contains a circuit for synaptic transmission. Inputs flow from the entorhinal cortex to the dentate gyrus (DG) via the perforant path, then synapse on cells in cornu Ammonis 3 ( $\left.\mathrm{CA}_{3}\right)$ via mossy fibers. $\mathrm{CA}_{3}$ axons may branch, forming Schaffer collateral axons which finally synapse on CA1 pyramidal neurons (Bear et al., 2016). Areas of this circuit are studied to investigate mechanisms of learning and memory such as long-term potentiation (LTP) and long-term depression (LTD), which are considered critical for learning and memory (Byrnes \& Vassoler, 2017). LTP and LTD are mechanisms of synaptic plasticity involving the strengthening and weakening of synapses. LTP is initiated by high frequency stimulation and results in the strengthening of synapses, whereas LTD is initiated by low frequency $(1-5 \mathrm{~Hz})$ stimulation and results in the weakening of synapses (Bear et al., 2016). N-methyl-D-aspartate
(NMDA) receptors also play a key role in learning and memory. Weak activation of NMDA receptors is linked to deficits in LTP and LTD, and poor learning and memory performances; whereas strong activation of this receptor enhances learning (Bear et al., 2016). Alterations of these learning and memory processes may be associated with opioid exposure in utero.

\section{Results and Discussion}

Seventeen rodent studies and six human studies were reviewed. Published studies on neurodevelopmental changes in rodents prenatally exposed to morphine and other opioids are summarized in Table 1 and Table 2, respectively. Both Tables 1 and 2 highlight the drug dosage given to the adult female rats or mice during pregnancy, and the duration of drug exposure for the fetuses. The results of neural and behavioural effects are focused on those of learning and memory and authors' comments/conclusions are provided accordingly. Each rodent study used similar methods to detect gestation (vaginal plug), and the rodents in these studies were given free access to food and water. Section 3.1 discusses the outcomes of the rodent studies, while studies on neurodevelopment in human children are discussed in Section 3.2.

\subsection{Drug Exposure and Effects on Rodents}

\subsubsection{Morphine}

In rodent models, prenatal exposure to morphine appears to produce a range of long-term or permanent neurological and behavioural deficits in the offspring (Yang et al., 2003; Tan et al., 2011; Eisch, Barrot, Schad, Self, \& Nestler, 2000). This may be the reason most of the studies in this review focused on prenatal exposure to morphine. Studies that investigate the effects of in utero morphine exposure generally show some forms of abnormalities in the learning and memory processes.

The reviewed studies have a common outcome of abnormalities within the hippocampus of the morphineexposed rodents. Most of the studies reported alterations in hippocampal processing including a decrease in synaptic complex interactions between NMDA subunits and postsynaptic density protein 95 (PSD-95) (Lin et al., 2009); reduced induction or maintenance of LTP (Niv et al., 2009; Tan et al., 2015; Velisek, Stanton, Moche, \& Vathy, 2000; Villarreal, Derrick, \& Vathy, 2008); or a decrease in LTD expression and therefore decrease in plasticity range (Yang et al., 2003). Some studies found an increase in the ratio of $\mathrm{Bax} / \mathrm{Bcl}-2$ and an increase in the expression of caspase-3 (Nasiraei-Moghadam, Kazeminezhad, Dargahi, \& Ahmandiani, 2010; Nasiraei-Moghadam et al., 2013); or a 
decrease in the expression of BDNF (Ahmadalipour et al., 2015; Nasiraei-Moghadam et al., 2013), suggesting an increase in cell-death signaling in the CNS. Each result of morphine-exposure, with the exception of one (NasiraeiMoghadam et al., 2010), was acquired from at least 14 days postnatal or more, further suggesting long-term or permanent neural effects. These findings propose impairments in learning and memory processes associated with morphine exposure in utero.

Along with the neural effects, studies that evaluated the behavioural effects of prenatal morphine exposure also appear to have relatively consistent results. Studies that evaluated changes in behaviour showed poor performance in behavioural tests on the prenatally exposed rodent offspring. There were poor performances in tests for anxiety (Klausz et al., 2011; Tan et al., 2015), exploration (Niu et al., 2009), depression (Klausz et al., 2011), and spatial learning and memory (Lin et al., 2009; Nasiraei-Moghadam et al., 2013; Yang et al., 2003), suggesting that the poor performance correlates with the depressing neural effects, as discussed previously.

Although most studies found a negative impact on learning and memory processes, one study revealed an increase in the amplitude of synaptic NMDA receptormediated currents in the morphine-exposed group (Yang et al., 2000). Yang et al. (2000) state that this discrepancy may be due to their focus on NMDA receptor kinetics at only synaptic sites and not at extrasynaptic sites. Additionally, two studies reported no abnormalities in LTP magnitude (Yang et al., 2003) or early-phase LTP (Villarreal et al, 2008). Yang et al. (2003) state that this inconsistency may be due to the difference in LTP induction protocol.

Nevertheless, the majority of the studies show that morphine negatively impacts neurodevelopment in offspring prenatally exposed to opioids, and that these effects could be long-term or permanent. Morphine may therefore be a good candidate for longitudinal studies on fetal opioid exposure and neural and behavioural changes.

\subsubsection{Other Opioids: Heroin, Oxycodone, LAAM, Buprenorphine, Methadone}

The next most-studied opioid in prenatal opioid exposure was heroin (Table 2). Heroin, also known as diacetylmorphine, is a derivative of morphine and is 4-8 times more potent than morphine (Wang \& Han, 2009). Each study on heroin showed suppressive neural effects in the exposed offspring, whether it was a significant increase in caspase-3 and Bax expression with a significant decrease in $\mathrm{BCl}-2$ in their hippocampi (Wang \& Han, 2009), or a decrease in dendrite length and branch number in the pyramidal neurons of their somatosensory cortex (Lu, Liu, Long, \& Ma, 2012). The effects on behaviour correlated with that of the CNS as the heroin-exposed offspring tended to perform poorly in tests for spatial learning and memory (Wang \& Han, 2009), and had less tendency to explore objects in new environments (Lu et al., 2012).

The results of heroin or morphine exposure in utero appear to be consistent with studies of other opioids such as oxycodone and the opiate LAAM (a long-acting mu-opioid receptor agonist) in terms of learning and memory changes. In both the oxycodone and LAAM studies, there were poor performances in tests of spatial learning and memory (Davis, Franklin, Johnson, \& Schrott, 2010; Schrott, Franklin, \& Serrano, 2008). Furthermore, it was found that the LAAMexposed offspring showed a decrease in the expression of BDNF precursor in their hippocampi (Schrott et al., 2008). One study, however, showed no significant difference in a test of spatial memory (T-maze test) between the oxycodone-exposed and control group (Davis et al., 2010). Davis et al. (2010) explain that this inconsistency may be due to the simplicity of the T-maze task. Nevertheless, it seems that regardless of which opioid is used, there is a common suppressive effect on learning and memory in rodents.

The current pharmacological intervention for pregnant women with opioid addiction is opioid maintenance therapy, which commonly uses opioids such as methadone and buprenorphine. Buprenorphine is a partial agonist at the mu-opioid receptor, and an antagonist at the kappa-opioid receptor (Konijnenberg \& Melinder, 2011). Prenatal buprenorphine exposure has been shown to reduce neural composition and BDNF expression, suggesting a decrease in neurogenesis in the exposed offspring (Wu et al., 2014). Buprenorphine exposure in utero was also found to be associated with depression-like behaviours (Wu et al., 2014). Interestingly, a study with methadone (a synthetic muopioid receptor agonist) did not show any effects on LTP, LTD, or spatial learning and memory in the offspring when it was administered alone to the pregnant rats (Chiang et al., 2015). However, methadone co-administered with the cough suppressant, dextromethorphan, appeared to alleviate pain and addiction-related abnormalities associated with methadone (Chiang et al., 2015). This finding suggests that methadone in combination with dextromethorphan may be a promising opioid replacement drug; however, further investigations of methadone's effects are required. The increased use of opioid maintenance therapy in pregnant women provides further incentives to direct these studies to human offspring.

\subsection{Neurodevelopment in Human Children}

Published studies on neurodevelopmental changes in human children prenatally exposed to opioids or a combination of opioids and nicotine or cocaine, are summarized in Table 3. Only six studies were chosen due to the limited amount of studies on the long-term effects of in utero opioid exposure in human children. 
Table 1. Summary of published studies on neurodevelopmental changes in rodent models prenatally exposed to morphine.

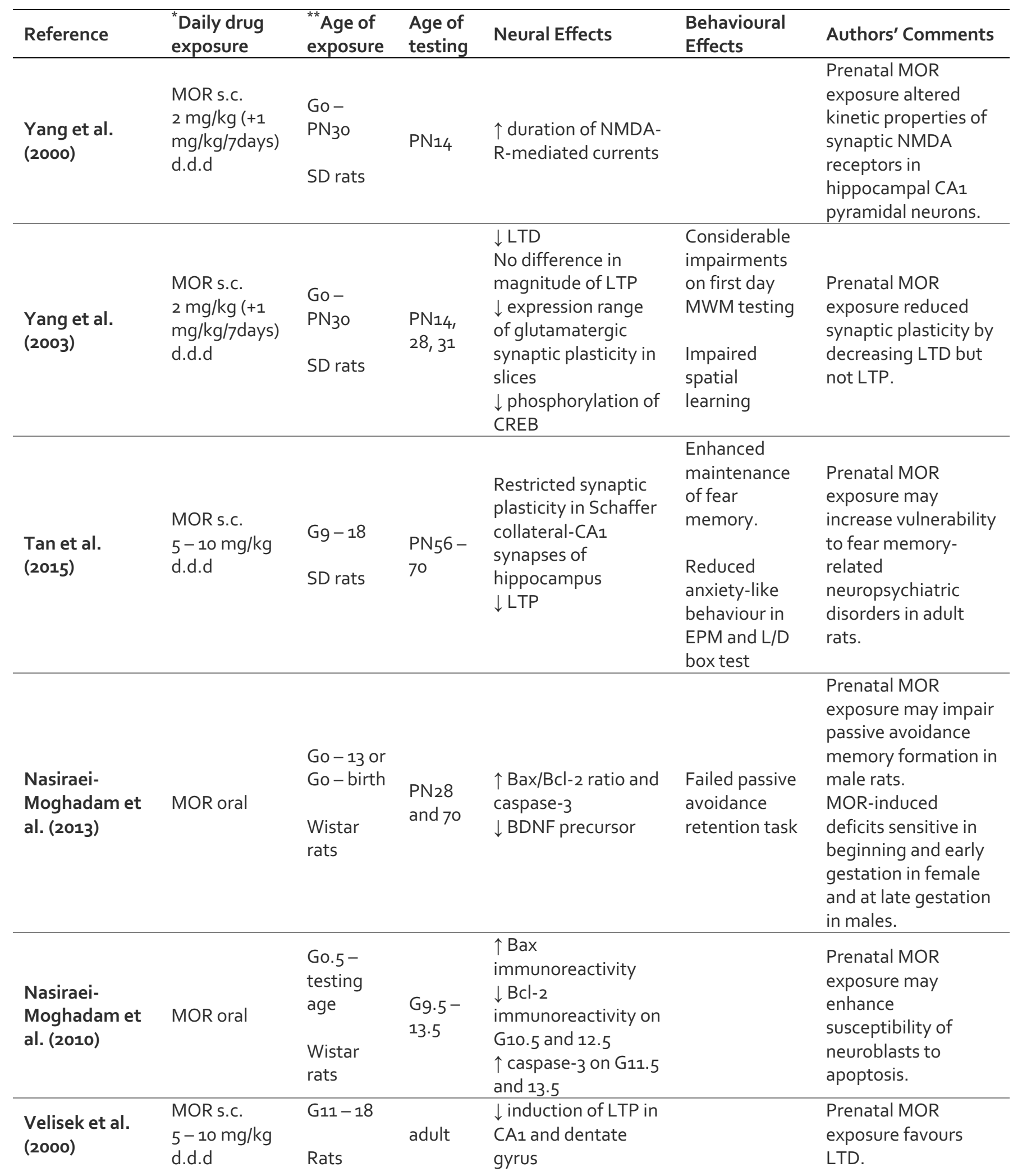




\begin{tabular}{|c|c|c|c|c|c|c|}
\hline $\begin{array}{l}\text { Villarreal et al. } \\
(2008)\end{array}$ & $\begin{array}{l}\text { MOR s.c. } \\
5-10 \mathrm{mg} / \mathrm{kg} \\
\text { d.d.d }\end{array}$ & $\begin{array}{l}\text { G11-18 } \\
\text { SD rats }\end{array}$ & $\begin{array}{l}P N_{109} \\
-120\end{array}$ & $\begin{array}{l}\downarrow \text { late-LTP } \\
\text { magnitude and } \\
\text { longevity in the } \\
\text { lateral (but not the } \\
\text { medial) perforant } \\
\text { path projections }\end{array}$ & & $\begin{array}{l}\text { Prenatal MOR } \\
\text { exposure disrupts } \\
\text { late LTP } \\
\text { maintenance. }\end{array}$ \\
\hline $\begin{array}{l}\text { Ahmadalipour } \\
\text { et al. (2015) }\end{array}$ & $\begin{array}{l}\text { MOR s.c. } \\
5-10 \mathrm{mg} / \mathrm{kg} \\
\text { d.d.d }\end{array}$ & $\begin{array}{l}\text { G11-18 } \\
\text { Wistar } \\
\text { rats }\end{array}$ & $\begin{array}{l}\mathrm{PN}_{51-} \\
57\end{array}$ & $\begin{array}{l}\downarrow \text { hippocampal BDNF } \\
\text { levels }\end{array}$ & & $\begin{array}{l}\text { Exposure to enriched } \\
\text { environment } \\
\text { decreases } \\
\text { behavioural deficits } \\
\text { induced by prenatal } \\
\text { MOR exposure. }\end{array}$ \\
\hline $\begin{array}{l}\text { Niu et al. } \\
(2009)\end{array}$ & $\begin{array}{l}\text { MOR s.c. } \\
5-10 \mathrm{mg} / \mathrm{kg} \\
\text { d.d.d }\end{array}$ & $\begin{array}{l}\text { G11- } 18 \\
\text { SD rats }\end{array}$ & $\begin{array}{l}\mathrm{PN}_{22}- \\
31\end{array}$ & $\begin{array}{l}\downarrow \text { LTP population } \\
\text { spike } \\
\downarrow \text { GABA-containing } \\
\text { neurons in dentate } \\
\text { gyrus }\end{array}$ & $\begin{array}{l}\downarrow \text { performance } \\
\text { in Y-maze task }\end{array}$ & $\begin{array}{l}\text { Prenatal morphine } \\
\text { exposure impairs DG } \\
\text { plasticity and spatial } \\
\text { memory in offspring; } \\
\text { decreased } \\
\text { GABAergic inhibition } \\
\text { may play a role. }\end{array}$ \\
\hline $\begin{array}{l}\text { Klausz et al. } \\
\text { (2011) }\end{array}$ & $\begin{array}{l}\text { MOR s.c. } \\
5-10 \mathrm{mg} / \mathrm{kg}\end{array}$ & $\begin{array}{l}\text { Go-end } \\
\text { of } \\
\text { lactation } \\
\text { Wistar } \\
\text { rats }\end{array}$ & $\begin{array}{l}\mathrm{PN} 23- \\
25 \text { and } \\
\text { adult }\end{array}$ & & $\begin{array}{l}\downarrow \text { time in open } \\
\text { arms of EPM } \\
\uparrow \text { time floating } \\
\text { and less time } \\
\text { climbing in } \\
\text { FST }\end{array}$ & $\begin{array}{l}\text { Anxiogenic } \\
\text { tendencies in EPM in } \\
\text { exposed rats, but } \\
\text { needs further } \\
\text { testing. } \\
\text { Perinatal MOR } \\
\text { exposure induces } \\
\text { long-term } \\
\text { depression-like } \\
\text { changes. }\end{array}$ \\
\hline $\begin{array}{l}\text { Lin et al. } \\
\text { (2009) }\end{array}$ & $\begin{array}{l}\text { MOR s.c. } \\
2 \mathrm{mg} / \mathrm{kg}(+1 \\
\mathrm{mg} / \mathrm{kg} / 7 \text { days }) \\
\text { d.d.d }\end{array}$ & $\begin{array}{l}\text { Go- } \\
\text { PN21 } \\
\text { SD rats }\end{array}$ & $\begin{array}{l}\mathrm{PN} 14, \\
45-58\end{array}$ & $\begin{array}{l}\downarrow \text { levels of PSD-95 } \\
\text { and NMDA subunits } \\
\text { and the interaction } \\
\text { between them }\end{array}$ & $\begin{array}{l}\downarrow \text { performance } \\
\text { in eight-arm } \\
\text { radial maze } \\
\text { task }\end{array}$ & $\begin{array}{l}\text { Prenatal MOR alters } \\
\text { connection of PSD- } \\
95 \text { with NMDA } \\
\text { subunits in } \\
\text { hippocampus which } \\
\text { leads to long-term } \\
\text { cognitive deficits. }\end{array}$ \\
\hline $\begin{array}{l}\text { Abbreviations: } \\
\text { postnatal day, } \\
\text { MWM - Morris } \\
\text { suspension test } \\
{ }^{*} \text { for adult femal }\end{array}$ & $\begin{array}{l}\text { 1OR - morphine } \\
\text { D - Sprague-Da } \\
\text { ater maze; EPN } \\
\text { GABA-gamm }\end{array}$ & $\begin{array}{l}\text { S.c. }- \text { subc } \\
\text { ley; CREB } \\
\text { - elevated } \\
\text { aminobut }\end{array}$ & $\begin{array}{l}\text { Ineous ir } \\
\text { yclic ade } \\
\text { ss maze; } \\
\text { acid; PS }\end{array}$ & $\begin{array}{l}\text { ection; d.d.d-double } \\
\text { osine monophospha } \\
\text { /D - light/dark; FST } \\
\text {-95 - postsynaptic d }\end{array}$ & $\begin{array}{l}\text { daily dose, } \mathrm{G}-\mathrm{g} \\
\text { response elem } \\
\text { forced swim test } \\
\text { nsity protein } 95 .\end{array}$ & $\begin{array}{l}\text { stational day; PN - } \\
\text { nt-binding protein; } \\
\text { TST - tail }\end{array}$ \\
\hline
\end{tabular}


Table 2. Summary of published studies on neurodevelopmental changes in rodent models prenatally exposed to opioids other than morphine.

\begin{tabular}{|c|c|c|c|c|c|c|}
\hline Reference & $\begin{array}{l}\text { *Daily drug } \\
\text { exposure }\end{array}$ & $\begin{array}{l}{ }^{* *} \text { Age of } \\
\text { exposure }\end{array}$ & $\begin{array}{l}\text { Age of } \\
\text { testing }\end{array}$ & Neural Effects & $\begin{array}{l}\text { Behavioural } \\
\text { Effects }\end{array}$ & Authors' Comment \\
\hline $\begin{array}{l}\text { Wang } \\
\text { and Han } \\
\text { (2009) }\end{array}$ & $\begin{array}{l}\text { HER s.c. } \\
10 \mathrm{mg} / \mathrm{kg}\end{array}$ & $\begin{array}{l}\text { G9-18 } \\
\text { Mice }\end{array}$ & $\begin{array}{l}\mathrm{PN}_{14} \\
\text { and PN } \\
30\end{array}$ & $\begin{array}{l}\uparrow \text { expression of } \\
\text { caspase- } 3 \text { and } \\
\text { Bax } \\
\downarrow \text { expression of } \\
\text { Bcl-2 }\end{array}$ & $\begin{array}{l}\downarrow \text { performance on } \\
\text { MWM test }\end{array}$ & $\begin{array}{l}\text { Prenatal HER exposure } \\
\text { enhances neuronal } \\
\text { apoptosis and impairs } \\
\text { hippocampus-dependent } \\
\text { learning and memory. }\end{array}$ \\
\hline $\begin{array}{l}\text { Lu et al. } \\
\text { (2012) }\end{array}$ & $\begin{array}{l}\text { HER s.c. } \\
10 \mathrm{mg} / \mathrm{kg} \\
\text { d.d.d }\end{array}$ & $\begin{array}{l}\text { G8.5- } \\
17.5 \\
\text { ICR mice }\end{array}$ & $\begin{array}{l}\mathrm{PN}_{3}, \\
62- \\
65,120\end{array}$ & $\begin{array}{l}\downarrow \text { dendrite length } \\
\text { and branch } \\
\text { number in } \\
\text { pyramidal } \\
\text { neurons in } \\
\text { somatosensory } \\
\text { cortex }\end{array}$ & $\begin{array}{l}\downarrow \text { tendency to } \\
\text { explore objects in } \\
\text { new } \\
\text { environments }\end{array}$ & $\begin{array}{l}\text { Prenatal administration of } \\
\text { addictive substances may } \\
\text { impair short-term } \\
\text { memory in adult } \\
\text { offspring. }\end{array}$ \\
\hline $\begin{array}{l}\text { Wu et al. } \\
(2014)\end{array}$ & $\begin{array}{l}\text { BUP } \\
\text { intraperitoneal } \\
1 \mathrm{mg} / \mathrm{kg}\end{array}$ & $\begin{array}{l}\text { G7 }-21 \\
\text { SD rats }\end{array}$ & PN21 & $\begin{array}{l}\downarrow \text { BDNF } \\
\text { expression } \\
\downarrow \text { in neuronal } \\
\text { composition } \\
\text { Impaired cell } \\
\text { proliferation and } \\
\text { neurogenesis }\end{array}$ & $\begin{array}{l}\text { Depression-like } \\
\text { neurobehaviours } \\
\text { from FST and } \\
\text { TST }\end{array}$ & $\begin{array}{l}\text { Prenatal BUP exposure } \\
\text { may result in depression- } \\
\text { like phenotypes, impaired } \\
\text { BDNF signalling and } \\
\text { expression, and decreased } \\
\text { neurogenesis. }\end{array}$ \\
\hline $\begin{array}{l}\text { Chiang et } \\
\text { al. (2015) }\end{array}$ & $\begin{array}{l}\text { MET s.c. } \\
\text { 5-7 mg/kg } \\
\text { d.d.d }\end{array}$ & $\begin{array}{l}\mathrm{G}_{3}-20 \\
\mathrm{SD} \text { rats }\end{array}$ & $\begin{array}{l}\mathrm{PN}_{14}- \\
21,30 \\
60\end{array}$ & $\begin{array}{l}\text { No effect on LTP, } \\
\text { or LTD }\end{array}$ & $\begin{array}{l}\text { No effect on } \\
\text { MWM }\end{array}$ & $\begin{array}{l}\text { Co-administration of } \\
\text { dextromethorphan with } \\
\text { MET prevented adverse } \\
\text { effects of prenatal MET } \\
\text { exposure. }\end{array}$ \\
\hline $\begin{array}{l}\text { Davis et } \\
\text { al. (2010) }\end{array}$ & $\begin{array}{l}\text { OXY } \\
\text { oral } \\
10-15 \mathrm{mg} / \mathrm{kg}\end{array}$ & $\begin{array}{l}\text { Go- } \\
\text { birth } \\
\text { SD rats }\end{array}$ & $\begin{array}{l}4-6 \\
\text { months }\end{array}$ & & $\begin{array}{l}\downarrow \text { performance in } \\
\text { radial arm maze } \\
\text { and long } \\
\text { interatrial interval } \\
\text { MWM test } \\
\text { No significant } \\
\text { difference in T- } \\
\text { maze test }\end{array}$ & $\begin{array}{l}\text { Prenatal OXY exposure } \\
\text { impairs spatial learning } \\
\text { and memory. }\end{array}$ \\
\hline $\begin{array}{l}\text { Schrott et } \\
\text { al. (2008) }\end{array}$ & $\begin{array}{l}\text { LAAM } \\
\text { oral } \\
1 \mathrm{mg} / \mathrm{kg}\end{array}$ & $\begin{array}{l}\text { Go- } \\
\text { birth } \\
\text { SD rats }\end{array}$ & adult & $\begin{array}{l}\downarrow \text { BDNF precursor } \\
\text { in hippocampus }\end{array}$ & $\begin{array}{l}\downarrow \text { performance on } \\
\text { radial arm maze } \\
\text { No difference in } \\
\text { retention testing }\end{array}$ & $\begin{array}{l}\text { Prenatal opiate exposure } \\
\text { or postnatal withdrawal } \\
\text { decreases expression of } \\
\text { proteins involved in neural } \\
\text { plasticity. }\end{array}$ \\
\hline \multicolumn{7}{|c|}{$\begin{array}{l}\text { Abbreviations: HER - heroin; BUP - buprenorphine; MET - methadone; OXY - oxycodone; LAAM - I- } \alpha \text { - } \\
\text { acetylmethadol; s.c. - subcutaneous injection; d.d.d - double daily dose; G - gestational day; PN - postnatal day; } \\
\text { SD - Sprague-Dawley; MWM - Morris water maze; FST - forced swim test; TST - tail suspension test. }\end{array}$} \\
\hline
\end{tabular}


Table 3. Summary of published studies on neurodevelopment in children prenatally exposed to opioids or opioids and other substances (nicotine or cocaine).

\begin{tabular}{|c|c|c|c|c|c|c|}
\hline Reference & $\mathrm{n}$ & Age & Drug & Control & Results & Authors' Comments \\
\hline $\begin{array}{l}\text { Bunikowski } \\
\text { et al. (1998) }\end{array}$ & 34 & $1 \mathrm{yr}$ & $\begin{array}{l}\text { Opiates and } \\
\text { nicotine }\end{array}$ & $\begin{array}{l}\text { Only } \\
\text { nicotine- } \\
\text { exposed }\end{array}$ & $\begin{array}{l}\downarrow \text { locomotor and } \\
\text { intellectual performance } \\
\downarrow \text { hearing and speech }\end{array}$ & $\begin{array}{l}\text { Infants prenatally exposed to } \\
\text { opiates are at risk for mild } \\
\text { impairments in psychomotor } \\
\text { development. } \\
\text { Neurological abnormalities } \\
\text { are more frequent in drug- } \\
\text { exposed group. }\end{array}$ \\
\hline $\begin{array}{l}\text { de Cubas } \\
\text { and Field } \\
\text { (1993) }\end{array}$ & 20 & $\begin{array}{l}6-13 \\
\text { yrs }\end{array}$ & Methadone & $\begin{array}{l}\text { Non- } \\
\text { exposed }\end{array}$ & $\begin{array}{l}\uparrow \text { anxiety, aggression, } \\
\text { rejection }\end{array}$ & $\begin{array}{l}\text { No significant difference on } \\
\text { cognitive tests, although } 10 \\
\text { scores were lower in exposed } \\
\text { group. }\end{array}$ \\
\hline $\begin{array}{l}\text { Hans and } \\
\text { Jeremy } \\
\text { (2001) }\end{array}$ & 33 & $\begin{array}{l}\text { birth- } \\
2 \text { yrs }\end{array}$ & Opioids & Non-opioid & $\begin{array}{l}\text { Slight } \downarrow \text { in mental and } \\
\text { psychomotor/motor } \\
\text { development indices }\end{array}$ & $\begin{array}{l}\text { Significantly poor mental } \\
\text { and motor development } \\
\text { during first } 2 \text { years of life in } \\
\text { prenatally exposed children, } \\
\text { however still within normal } \\
\text { range. }\end{array}$ \\
\hline $\begin{array}{l}\text { Hunt et al. } \\
\text { (2008) }\end{array}$ & 133 & $\begin{array}{l}18 \\
\text { mths } \\
\text { and } 3 \\
\text { yrs }\end{array}$ & Opiates & Drug-free & $\begin{array}{l}\downarrow \text { scores in all assessment } \\
\text { tools except } \\
\text { psychomotor } \\
\text { development index of } \\
\text { Bayley Scales of Infant } \\
\text { Development }\end{array}$ & $\begin{array}{l}\text { Infants exposed to opiates in } \\
\text { utero are at increased risk of } \\
\text { neurodevelopmental } \\
\text { problems throughout early } \\
\text { childhood. }\end{array}$ \\
\hline $\begin{array}{l}\text { Messinger } \\
\text { et al. (2004) }\end{array}$ & 98 & $\begin{array}{l}1-3 \\
\text { yrs }\end{array}$ & $\begin{array}{l}\text { Opiate or } \\
\text { opiate and } \\
\text { cocaine }\end{array}$ & $\begin{array}{l}\text { Cocaine or } \\
\text { non-opiate } \\
\text { and non- } \\
\text { cocaine }\end{array}$ & $\begin{array}{l}\downarrow \text { psychomotor } \\
\text { development index } \\
\text { Neither the cocaine nor } \\
\text { opiate effect remained } \\
\text { significant after } \\
\text { controlling for co- } \\
\text { varieties }\end{array}$ & $\begin{array}{l}\text { Infant prenatal exposure to } \\
\text { cocaine and to opiates was } \\
\text { not associated with mental, } \\
\text { motor, or behavioural } \\
\text { deficits after controlling for } \\
\text { birth weight and } \\
\text { environmental risks. }\end{array}$ \\
\hline $\begin{array}{l}\text { Wahlsten } \\
\text { and Sarman } \\
\text { (2013) }\end{array}$ & 28 & $\begin{array}{l}5-6 \\
y r s\end{array}$ & Buprenorphine & $\begin{array}{l}\text { General } \\
\text { population }\end{array}$ & $\begin{array}{l}\text { Visual motor and } \\
\text { attention problems in } \\
\text { WPPSI-R scales } \\
\text { Problems in motor skills } \\
\text { and memory abilities } \\
\text { from McCarthy scales } \\
\uparrow \text { hyperactivity, } \\
\text { impulsivity, attention } \\
\text { problems in Brown ADD } \\
\text { scale and SDQ tests }\end{array}$ & $\begin{array}{l}\text { Children to opiate-addicted } \\
\text { mothers with buprenorphine } \\
\text { maintenance treatment } \\
\text { during pregnancy constitute } \\
\text { a risk population. }\end{array}$ \\
\hline
\end{tabular}

Abbreviations: $\mathbf{n}$ - number of subjects prenatally exposed to the drug in test, IQ - Intelligence Quotient, WPPSI-R Wechsler Preschool and Primary Scale of Intelligence-Revised, ADD - Attention-Deficit Disorder, SDO - Strengths and Difficulties Questionnaire 


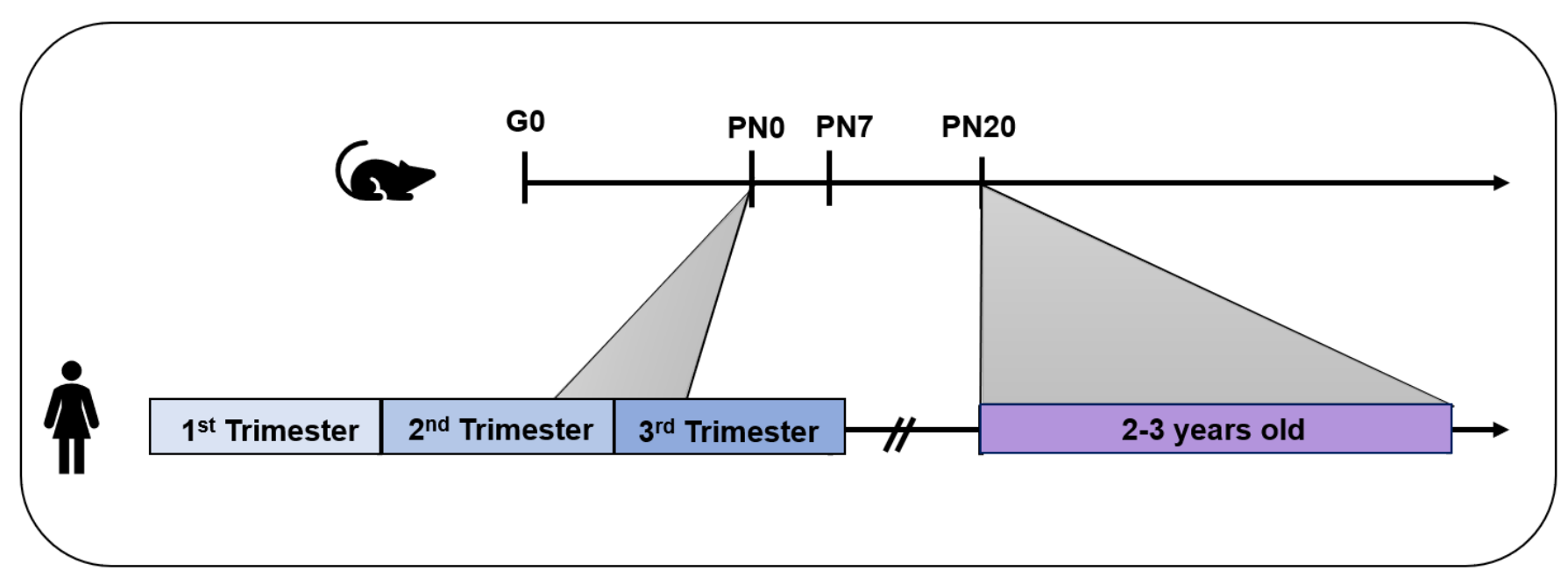

Figure 1. A schematic illustration and comparison of neurodevelopment in the gestational and postnatal (PN) periods of rodents and humans as measured by brain weight. PNo in rodents corresponds to late $2^{\text {nd }}$ trimester to late $3^{\text {rd }}$ trimester in humans, PN7 in rodents corresponds to the birth of a human child, and PN2O in rodents corresponds to the human infant at age 2 to 3 years (Byrnes \& Vassoler, 2017; Semple et al., 2013).

The studies reviewed reported decreases in intellectual performance, psychomotor, locomotor, and visual motor development, as well as abnormalities in anxiety, aggression, hyperactivity, and attention (Table 3). Additionally, one study reported complications with memory in the opioid-exposed group (Wahlsten \& Sarman, 2013). Some studies reported notable differences in the exposed group from the control (Hans \& Jeremy, 2001; Wahlsten \& Sarman, 2013; Bunikowski et al., 1998; Hunt, Tzioumi, Collins, \& Jeffery, 2008), whereas other studies reported insignificant differences (de Cubas \& Field, 1993), or no overall significant difference after correcting for covariates (Messinger et al., 2004). These studies suggest that infants who were prenatally exposed to opioids are more susceptible to impairments in psychomotor development and neurodevelopment. However, the impairments may only be acute or not clinically significant.

The heterogeneity of the results may be attributed to numerous factors associated with opioid dependence or addiction. It is common for opioid addicted individuals, including women of the childbearing age, to use combinations of drugs and alcohol. The duration of exposure of the fetus to the opioids may also play a role, along with any environmental factors that the infant is exposed to after birth. Additionally, Byrnes and Vassoler (2017) suggest that mother-child interactions, unknown genetic variabilities, and diverse underlying mechanisms (which are likely influenced by drug type, dose, and duration) also play a role. In the following section, various influencing factors (as considered in the rodent models) will be discussed to outline the advantages and disadvantages of using rodent models for studies on prenatal opioid exposure.

\subsection{Factors Influencing Neurodevelopmental Outcomes}

With the variabilities in results and numerous influencing factors, it seems reasonable to turn towards animal models to study neurodevelopmental effects of prenatal opioid exposure. With rodent models, the duration of gestation is shorter, and the researchers have more control over various factors such as dose, environmental conditions, and time and duration of exposure. The rodent model may provide researchers insight to how the human infant brain can be affected; but only to a certain extent due to distinctions such as the complexity of the human brain, differences in developmental timing, and differences in animal behaviour between rodents and humans.

\subsubsection{Age}

As shown in Tables 1 and 2, the majority of the rodent studies in review exposed the offspring to opioids during the entire period of gestation or the last two-thirds of gestation and evaluated the offspring between postnatal day 14 and 6 months (adulthood). Morphine studies that measured LTP after drug exposure during the last two-thirds of gestation showed some form of LTP alteration; however, one study that investigated LTP after drug exposure throughout the entire gestation period showed no difference in LTP (Table 1). Although this data suggests that LTP alterations are dependent on drug exposure timing, more studies on prenatal opioid exposure and LTP effects are needed to support this proposal. No other clear distinctions were shown from neural or behavioural effects due to variations in the age of exposure or age of testing. 

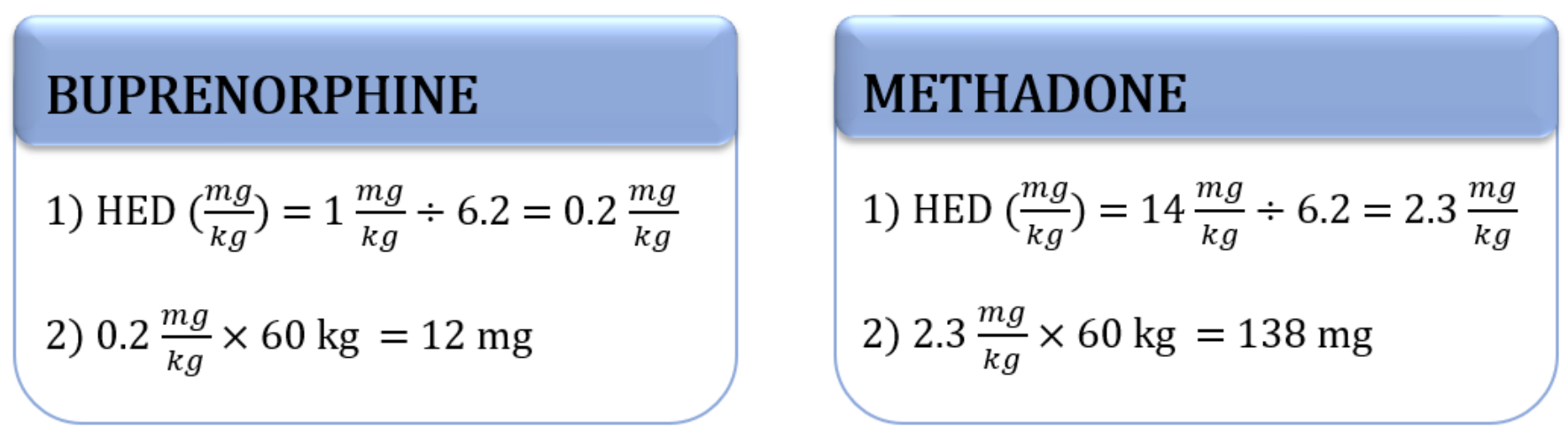

HED - Human Equivalent Dose

Figure 2. Steps of Human Equivalent Dose calculations for buprenorphine and methadone (Nair \& Jacob, 2016).

In the human studies, the children evaluated at birth to age 6 years showed impairments in neurodevelopment compared to the control, regardless of which opioid or polysubstance was taken (Bunikowski et al., 1998; Hans \& Jeremy, 2001; Hunt et al., 2008; Messinger et al., 2004; Wahlsten \& Sarman, 2013). However, one study which evaluated children between the ages of 6 to 13 years who were prenatally exposed to methadone reported no significant differences in cognitive tests (de Cubas \& Field, 1993). Together, these observations could either imply that methadone has minimal adverse effects on cognition or the effects of prenatal opioid exposure on cognition are not permanent.

An important question yet to be answered is what age in rodents best corresponds to the human at the premature, newborn, infant, or child age (Semple, Blomgren, Gimlin, Ferriero \& Noble-Haeusslein, 2013)? Rodents typically have a gestational period of 21-22 days as compared to humans, which consists of a typical 40-week period (Semple et al., 2013). Many measures of neurodevelopment in rodents are considered at birth/postnatal day zero and are comparable to the latesecond trimester to early-third trimester of the human fetus (Byrnes \& Vassoler, 2017). As shown in Figure 1, postnatal day 7 in rodents is considered to correspond to the human infant at birth, and postnatal day 20 in rodents is considered to correspond to the human child at 2 to 3 years of age (Semple et al., 2013). However, these measurements only account for brain weight and do not reflect other factors such as heterogeneity between brain regions which mature at different rates (Semple et al., 2013).

There is difficulty in comparing the results of rodents to humans, as rodent studies that expose the offspring to opioids throughout gestation only show results that are comparable to opioid exposure in humans during both the first and early second trimester (Byrnes and Vassoler, 2017). This limitation between the rodent and human gestation period results in failure to account for the exposure in the late-second trimester to the early-third trimester of the human fetus, where rapid brain development occurs.

The data from the rodent studies suggest that impairments of neurodevelopment in utero may lead to longterm complications; however, this inference cannot be concluded due to the limited number of studies. Furthermore, the difference in gestation periods between rodents and humans continues to provide complications when using rodent models to mimic the effects in humans.

\subsubsection{Drug Usage}

The dosage in the buprenorphine and methadone rodent studies resembled typical doses given in opioid maintenance therapy. Using the human equivalent dose (HED) calculation (Nair \& Jacob, 2016), the rodent dosage of buprenorphine and methadone were converted to their human equivalent (Figure 2). A comparison of the average clinical daily dose of buprenorphine (15.1 mg) (Wahlsten \& Sarman, 2013) and methadone (up to $200 \mathrm{mg}$ ) (Chiang et al., 2015) to the calculated HED (12 mg for buprenorphine and $138 \mathrm{mg}$ for methadone) shows that the doses used in the rodent studies were reasonable. Since buprenorphine and methadone were the only opioids investigated solely in the human studies, only the doses of these two drugs are compared here.

Of the morphine rodent studies, most delivered 5 $10 \mathrm{mg} / \mathrm{kg}$ twice daily, some gradually increased the daily dose to about $10 \mathrm{mg} / \mathrm{kg}$ throughout gestation, and one administered $5-10 \mathrm{mg} / \mathrm{kg}$ once a day. Regardless of dosage, each morphine study showed some form of abnormality in either neurodevelopment or behaviour (Table 1). Furthermore, as shown in Table 2, whether or not heroin dosage was doubled, similar neural and behavioural effects were produced (Wang \& Han, 2009; Lu et al., 2012). Comparing the studies by Nasiraei-Moghadam et al. (2010) and Ahmadalipour et al. (2015), no matter if the drug was administered orally or subcutaneously, there was a decrease 
in the expression of BDNF. Therefore, variations in dosage or form of drug administration as applied in the studies did not seem to significantly affect the neural and behavioural results of the rodents.

\subsubsection{Environmental and Other Factors}

Environmental factors seem to play a role in the results of the studies. In fact, each of the human studies in review deliberately focused on participants who had a low socioeconomic status or considered it to be an important variance. Children in families of low socioeconomic status performed poorly on tests of behaviour, and psychomotor development (Messinger et al., 2004) (Table 3). These environmental effects do not go unnoticed in the rodent models. The study by Ahmadalipour et al. (2015) shows that exposure to enriched environments decreases the behavioural deficits that were induced by prenatal morphine exposure (Table 1). Genetic differences and epigenetic changes also appear to play a role in the variability of the effects in humans (Wachman et al., 2014); however, this topic is beyond the scope of this paper.

Whether the effects of prenatal opioid exposure to the offspring is due to the opioid itself, or the opioid being the prime factor, is still not clear. As discussed, various factors may also contribute to the neural and behavioural outcomes, creating difficulty in preventing the effects of opioid exposure in utero.

\section{Recommendations for Future Studies}

The limited number of studies on the long-term neurodevelopmental changes in human offspring prenatally exposed to opioids may be due to lack of participation. Participation in studies such as ones that evaluate opioid exposure (especially if opioids were used illicitly) in utero appears to be low. It is improbable that drug-addicted pregnant women will participate or conform in such studies potentially because of the fear of arrest for possession of illegal substances, or, more commonly, for fear of losing their child to child protective services (Nygaard, Slinning, Moe, \& Walhovd, 2017). A possible way to increase the participation rates in the human studies is to focus on legal opioids such as pain killers and to provide incentives such as rehabilitation afterwards.

As mentioned previously, the current pharmacological intervention for opioid-addicted or dependent pregnant women is opioid maintenance therapy. Synthesis of novel opioids that are less likely to cross the placenta is recommended to be studied as a novel pharmacological approach for preventing the exposure of the fetus to opioids during the critical period of brain development. However, this will not solve the issue of treating the opioid addicted or dependent mother.
Further studies on dextromethorphan, which has been shown to counteract the suppressive effect of opioids on learning and memory processes in rodent models (Chiang et al., 2015), are required. This may provide additional methods of suppressing neurodevelopmental effects from prenatal opioid exposure.

\section{Conclusion}

The studies showed a general impairment of learning and memory processes in the rodent models, and impairment in cognition, behaviour, attention, learning and memory in human children who were exposed to opioids in utero. Various factors such as the environment and drug dosage/exposure may play some role in the diversity (significant differences and non-significant differences) of results in both the human and rodent models. Whether these changes are due to the opioid alone or opioid and (an)other substance(s) is still not clear.

This review shows that prenatal opioid exposure in human children has an effect on neurodevelopment and that the rodents that were exposed may have impaired learning and memory. Rodent models can provide insight into the neurodevelopmental changes that may occur in humans. However, due to the differing gestation periods and differing critical periods of brain development in rodents and humans, it is difficult to say that these changes will occur with great certainty. The limited number of studies on prenatal opioid exposure in human infants and the lack of knowledge on the long-term outcomes is unfortunate. With the clinical use of opioid maintenance therapy given to dependent or addicted pregnant women, further investigations of the effects of early opioid exposure on neurodevelopment in the offspring are required. Moreover, investigating other methods of preventing/attenuating the effects of in utero opioid exposure is recommended.

\section{Acknowledgements}

I would like to express my sincerest gratitude to Dr. John Howland who provided me the opportunity of writing this review paper as a class project, and encouraged me to submit for publication. His encouragement, generosity, and suggestions have been greatly appreciated.

University of Saskatchewan Undergraduate Research Journal 


\section{References}

Ahmadalipour, A., Sadeghzadeh, J., Vafaei, A. A., Bandegi, A. R., Mohammadkhani, R., \& Rashidy-Pour, A. (2015) Effects of environmental enrichment on behavioural deficits and alterations in hippocampal BDNF induced by prenatal exposure to morphine in juvenile rats. Neuroscience 305, 372-383.

Bear, M. F., Connors, B. W., \& Paradiso, M. A. (2016) Neuroscience: Exploring the Brain. Philadelphia: Wolters Kluwer.

Brogly, S. B., Turner, S., Lajkosz, K., Davies, G., Newman, A., Johnson, A., \& Dow, K. (2017) Infants Born to Opioid-Dependent Women in Ontario, 2002-2014. J Obstet Gynaecol Can 39(3), 157-165.

Bunikowski, R., Grimmer, I., Heiser, A., Metze, B., Schafer, A., \& Obladen, M. (1998)Neurodevelopmental outcome after prenatal exposure to opiates. Eur J Pediatr 157, 724-730.

Byrnes, E. M., \& Vassoler, F. M. (2017) Modeling prenatal opioid exposure in animals: Current findings and future directions. Frontiers of Neuroendocrinology $51,1-13$.

Chiang, Y. C., Ye, L. C., Hsu, K. Y., Liao C. W., Hung, T. W., Lo, W. J., Ho, I. K., \& Tao, P. (2015) Beneficial effects of co-treatment with dextromethorphan on prenatally methadone-exposed offspring. $J$ of Biomedical Sci 22(19), 1-12.

Cominski, T. P., Ansonoff, M. A., Turchin, C. E., \& Pintar, J. E. (2014) Loss of the mu opioid receptor induces strain-specific alterations in hippocampal neurogenesis and spatial learning. Neuroscience 278, 11-19.

Davis, C. P., Franklin, L. M., Johnson, G. S., \& Schrott, L. M. (2010) Prenatal oxycodone exposure impairs spatial learning and/or memory in rats. Behavioural Brain Research 212(1), 27-34.

de Cubas, M. M. \& Field, T, (1993) Children of methadonedependent women: developmental outcomes. Amer J Orthropsychiat 63(2), 266-276.

Eisch, A. J., Barrot, M., Schad, C. A., Self, D. W., \& Nestler, J. (2000) Opiates inhibit neurogenesis in the adult rat hippocampus. Proc Natl Acad Sci U.S.A 97(13), 7579-7584.
Hans, S. L., \& Jeremy, R. J. (2001) Postneonatal mental and motor development of infants exposed in utero to opioid drugs. Infant Mental Health J 22(3),300-315.

Hunt, R. W., Tzioumi, D., Collins, E., \& Jeffery, H. E. (2008) Adverse neurodevelopmental outcome of infants exposed to opiate in-utero. Early Human Development 84, 29-35.

Klausz, B., Pinter, O., Sobor, M., Gyarmati, Z., Furst, Z., Timar, J., \& Zelena, D. (2011) Changes in adaptability following perinatal morphine exposure in juvenile and adult rats. Eu $J$ of Pharmacology 654, 166-172.

Konijnenberg, C., \& Melinder, A. (2011) Prenatal exposure to methadone and buprenorphine: A review of the potential effects on cognition development. Child Neuropsychology17, 495-519.

Lin, C. S., Tao, P. L., Jong, Y. J., Chen, W. F., Yang, C. H., Huang, L. T., Chao, C. H., \& Yang, S. N. (2009) Prenatal morphine alters the synaptic complex of postsynaptic density 95 with $N$-methyl-D aspartate receptor subunit in hippocampal CA1 subregion of rat offspring leading to long term cognitive deficits. Neuroscience 158, 1326-1337.

Lu, R., Liu, Z., Long, H., \& Ma, L. (2012) Effects of prenatal cocaine and heroin exposure on neuronal dendrite morphogenesis and spatial recognition memory in mice. Neuroscience Letters522, 128-133.

Messinger, D. S., Bauer, C.R., Das, A., Seifer, R., Lester, B.M., Lagasse, L.L., ... Poole, W.K. (2004) The Maternal Lifestyle Study: Cognitive, Motor, and Behavioural Outcomes of Cocaine Exposed and Opiate-Exposed Infants Through Three Years of Age. Pediatrics 113(6), 1677-1685.

Nair, A. B., \& Jacob, S. (2016) A simple practice guide for dose conversion between animals and human. $J$ Basic Clin Pharm, 7(2), 27-31.

Nasiraei-Moghadam, S., Kazeminezhad, B., Dargahi, L., \& Ahmadiani, A. (2010) Maternal Oral Consumption of Morphine Increases $\mathrm{Bax} / \mathrm{Bcl}-2$ Ratio and Caspase 3 Activity During Early Neural System Development in Rat Embryos. J Mol Neurosci 41, 156-164.

Nasiraei-Moghadam, S., Sherafat, M.A., Safari, M.S., Moradi, F., Ahmadiani, A., \& Dargahi, L. (2013) Reversal of Prenatal Morphine Exposure-Induced 
Memory Deficit in Male But Not Female Rats. $J$ Mol Neurosci 50, 58-69.

Niu, L., Cao, B., Zhu, H., Mei, B., Wang, M., Yang, Y., \& Zhou, Y. (2009) Impaired in vivo synaptic plasticity in dentate gyrus and spatial memory in juvenile rates induced by prenatal morphine exposure. Hippocampus 19(7), 649-657.

Nygaard, E., Slinning, K., Moe, V., \& Walhovd, K.B. (2017) Cognitive function of youths born to mothers with opioid and poly-substance abuse problems during pregnancy. Child Neuropsychology 23(2), 159-187.

Patrick, S.W., Schumacher, R.E., Benneyworth B. D., Krans, E. E., McAllister, J. M., \& Davis, M. M. (2012) Neonatal Abstinence Syndrome and Associated Health Care Expenditures: United States, 20002009. JAMA 307(18), 1934-1940.

Polunina, A.G., \& Bryun, E.A. (2013) Neuropsychological Functions of $\mu$ - and $\delta$-Opioid Systems. ISRN Addiction 2013, 1-13.

Schrott, L.M., Franklin, L.M., \& Serrano, P.A. (2008) Prenatal opiate exposure impairs radial arm maze performance and reduces levels of BDNF precursor following training. Brain Research 1198, 132-140.

Semple, B.D., Blomgren, K., Gimlin, K., Ferriero, D.M., \& Noble-Haeusslein, L.J. (2013) Brain development in rodents and humans: Identifying benchmarks of maturation and vulnerability to injury across species. Progress in Neurobiology 106, 1-16.

Stover, M.W. \&Davis, J.M. (2015) Opioids in Pregnancy and Neonatal Abstinence Syndrome. Semin Perinatal 39(7), 561-565

Tan, J.W., Duan, T.T., Zhou, Q.X., Ding, Z.Y., Jing, L., Cao, J., ... Xu, L. (2015) Impaired contextual fear extinction and hippocampal synaptic plasticity in adult rats induced by prenatal morphine exposure. Addict Biol 20(4), 652-662.

Velisek, L., Stanton, P.K., Moshe, S.L., \& Vathy, I. (2000) Prenatal morphine exposure enhances seizure susceptibility but suppresses long-term potentiation in the limbic system of adult male rats. Brain Research 61(6), 571-576.

Villarreal, D.M., Derrick, B., \& Vathy, I. (2008) Prenatal Morphine Exposure Attenuates the Maintenance of Late LTP in Lateral Perforant Path Projections to the Dentate Gyrus and the $\mathrm{CA}_{3}$ Region In Vivo. J Neurophysiology 99(3), 1235-1242.

Wachman, E.M., Hayes, M.J., Lester, B.M., Terrin, N., Brown, M.S., Nielsen, D.A., \& Davis, J.M. (2014) Epigenetic Variation in the Mu-Opioid Receptor Gene in Infants with Neonatal Abstinence Syndrome. J of Pediatrics 165(3), 472-478.

Wahlsten, V.S. \& Saman, I. (2013) Neurobehavioral development of preschool-age children born to addicted mothers given opiate maintenance treatment with buprenorphine during pregnancy. Acta Paediatrica 102, 544-549.

Wang, Y., \& Han, T.Z. (2009) Prenatal exposure to heroin in mice elicits memory deficits that can be attributed to neuronal apoptosis. Neuroscience 160, 330-338.

Wu, C.C., Hung, C.J., Shen, C.H., Chen, W.Y., Chang, C.Y., Pan, H.C., Liao, S.L., \& Chen, C.J. (2014) Prenatal buprenorphine exposure decreases neurogenesis in rats. Toxicology Letters 225, 92-101.

Yang, S.N., Huang, L.T., Wang, C.L., Chen, W.F., Yang, C.H., Lin, S.Z., Lai, M.C., Chen, S.J., \& Tao, P.L. (2003) Prenatal Administration of Morphine Decreases CREBSerine-133 Phosphorylation and Synaptic Plasticity Range Mediated by Glutamatergic Transmission in the Hippocampal $\mathrm{CA}_{1}$ Area of Cognitive-Deficient Rat Offspring. Hippocampus 13, 915-921.

Yang, S.N., Yang, J.M., Wu, J.N., Kao, Y.H., Hsieh, W.Y., Chao, C.C., \& Tao, P.L. (2000) Prenatal Exposure to Morphine Alters Kinetic Properties of NMDA Receptor-Mediated Synaptic Currents in the Hippocampus of Rat Offspring. Hippocampus 10, 654-662. 
Prenatal Opioid Exposure: A Review (Quagraine)

University of Saskatchewan Undergraduate Research Journal 